\title{
Diagnostic Value of Matrix Metalloproteinases MMP-2 and MMP-9 in Synovial Fluid for Identifying Osteoarthritis in the Distal Interphalangeal Joint in Horses
}

\author{
P. ZRIMŠEK, V. KADUNC KOS, J. MRKUN, M. KOSEC
}

Clinic for Reproduction and Horses, Veterinary Faculty, University of Ljubljana, Slovenia

Received July 14, 2005

Accepted September 5, 2006

\begin{abstract}
Zrimšek P., V. Kadunc Kos, J. Mrkun, M. Kosec: Diagnostic Value of Matrix Metalloproteinases MMP-2 and MMP-9 in Synovial Fluid for Identifying Osteoarthritis in the Distal Interphalangeal Joint in Horses. Acta Vet Brno 76, 2007: 87-95.

Our aim was to examine the diagnostic potential of matrix metalloproteinases MMP-2 and MMP-9 for identifying osteoarthritis in the horse.

Horses were divided into two groups - a positive group consisting of 28 horses with cartilage damage in the distal interphalangeal joint and a negative group of 17 control horses. Clinical examination of the horses included evaluation of lameness, flexion test, diagnostic nerve blocks, X-ray and arthroscopy. MMP-2 and MMP-9 were detected in synovial fluid using gelatin zymography.

Monomers of MMP-2 and MMP-9 appeared not to be specific for osteoarthritis since they also occurred in control samples. In contrast, detection of active forms of MMPs was found to be more effective than radiological examination in identifying horses with osteoarthritis, on the grounds of higher sensitivity. Active forms of MMP-2 and MMP-9 were observed with $88.24 \%$ and $82.35 \%$ specificity respectively, indicating the high accuracy in correctly identifying horses without osteoarthritis. Thus, as an addition to clinical examination, detection of MMPs could improve the diagnosis of osteoarthritis. Detection of active forms of MMP-2 and MMP-9 was evaluated as an additional diagnostic tool in diagnosing osteoarthritis, especially in the case of a negative X-ray result. The proportions of animals with confirmed osteoarthritis, which tested positive, were found to be $81.82 \%$ and $76.92 \%$, respectively. The results of this study confirm that active forms of MMP occur in synovial fluid of osteoarthritic joints more frequently than in synovial fluid from normal joints of the horse. Detection of active forms of MMP-2 and MMP-9 is shown to have an important diagnostic potential.
\end{abstract}

MMP-2, MMP-9, diagnostic evaluation, osteoarthritis, distal interphalangeal joint, horse

Degenerative joint disease (osteoarthritis) is common in athletic horses, occurring as a result of trauma or in association with excessive use of the joint during training and performance. Degenerative joint disease is characterised by destruction and loss of articular cartilage, poor cartilage repair, changes to the subchondral bone plate and inflammation of the synovial membrane (synovitis) and joint capsule (capsulitis) (McIlwraith and Vachon 1988). Inflamed synovia is a source of inflammatory mediators and enzymes capable of destroying articular cartilage ( Gibs on et al. 1996).

Early diagnosis of OA is a major problem, in both human and veterinary medicine. Visible lesions of articular cartilage are present and can be detected using arthroscopy, which is a successful but invasive method. The use of markers from synovial fluid in diagnostic of osteoarthritis could have a great potential in diagnosing the disease at an earlier stage, in monitoring pathological changes of the disease and the effects of treatment (Rørvik and Grøndahl 1995; McIlwraith 2005).

Chondrocytes appear to play an important role in both the physiological metabolism of cartilage matrix in development and growth, and in the pathological degradation that occurs in joint disease (Lohmander et al. 1992). The degradative activity of chondrocytes and

Address for correspondence:

P. Zrimšek

Clinic for Reproduction and Horses,

Veterinary Faculty, University of Ljubljana

Gerbičeva 60, 1000 Ljubljana, Slovenia
Phone: +3861477927

Fax: +386112832 243

E-mail: petra.zrimsek@vf.uni-lj.si

http://www.vfu.cz/acta-vet/actavet.htm 
fibroblasts is greatly stimulated by cytokines such as interleukin-1 or tumour necrosis factor (TNF) released from cells of the synovia or perhaps by the chondrocytes themselves, and this has been suggested to be an important mechanism in inflammatory joint disease (Cruwys et al. 1990; Lefebvre et al. 1990). The primary cleavage of cartilage matrix molecules is extracellular and is mediated by proteinases. A central role in cartilage matrix degradation has been proposed for the metalloproteinase family (W oes s ner 1991). Matrix metalloproteinases (MMPs) are a family of nine or more highly homologous $\mathrm{Zn}(++)$ endopeptidases that collectively cleave most, if not all, of the constituents of the extracellular matrix (Birkedal-Hansen et al. 1993). They are important in remodelling events and the migration of cells through the extracellular matrix (Birkedal-Han sen et al. 1993; Allan et al. 1995; Clegg et al. 1997; Koolwijk et al. 1995) and also in tumour growth and metastasis, promoting the migration and invasion of cells ( $\mathrm{Sier}$ et al. 2000).

MMP-2 is constitutively expressed by many cell types and is most probably regulated at the level of proenzyme activation, whereas MMP-9 is transcriptionally regulated by inflammatory cytokines such as tumour necrosis $\alpha$ and interleukins (Leber and Balkwill 1998). MMPs are secreted as inactive zymogens. Their activation is a fundamental step in articular cartilage degradation, which requires loss of an 8 to $10 \mathrm{kDa}$ N-terminal propeptide (Birkedal-Hansen et al. 1993). The extracellular activation of the latent pro-forms of metalloproteases can take place by several different pathways, in which a cascade involving plasminogen activators and plasmin may play a major role (Woes ner 1991). Inhibition of MMP activity can occur both by local tissue inhibitors of metalloproteases (TIMPs) (Clegg et al. 1998) and systemically by $\alpha-2$ macroglobulin (Birkedal-Hansen et al. 1993). TIMPs can inhibit metalloprotease activity at the level of activated enzyme and also at the level of proenzyme activation (Clegg and Carter 1999). An imbalance between TIMP and metalloproteases that favours an increased level of the active enzyme is a contributing factor in the enzymatic degradation of articular cartilage (Pelletier et al. 1990). An increase in metalloproteinase activity may be caused by either an increase in the amount of activated enzyme or by a decrease in the amount of available inhibitor, or both. Such perturbations in the equilibrium between the enzyme and inhibitors have been shown to occur in osteoarthritic cartilage and metastatic cells (Dean et al. 1989; Ponton et al. 1991; Koolwijk et al. 1995; Clegg et al. 1998).

Our work is one of the studies investigating the importance of MMP-2 and MMP-9 causing matrix degradation in horse joints. It is focused on the contribution of MMP assays to clinical decision making. In the present article matrix metalloproteases are proposed as a potential diagnostic marker in the diagnosis of osteoarthritis in the distal interphalangeal joint, which is one of the most commonly affected joints in the horse.

\section{Materials and Methods}

Horses

All clinical cases were referred by veterinary surgeons at the Clinic for Reproduction and Horses, Veterinary Faculty, University of Ljubljana, Slovenia and to the Equine Clinic in Zorneding, Germany.

All horses with lameness were subjected to further clinical examination including flexion test, diagnostic nerve blocks, X-ray and arthroscopy. Diagnostic nerve blocks were used for the localisation of the pain. Arthroscopy was performed on dorsal approach using arthroscope with $30^{\circ}$. In the positive group of horses only those with cartilage damage in the distal interphalangeal joint found with arthroscopy were included. Thus, cartilage damage found in the distal interphalangeal joint in the lame horse by arthroscopic examination was the basis for the selection of horses for the positive group (all 4 years or more old (age 4 - 16, average 9.3 years)).

The negative group included control horses subjected to euthanasia for conditions unrelated to orthopaedic disease (age 4 - 13, average 7.8 years). No lameness was observed in those horses. All examinations performed in the group of positive horses, were also performed in the group of control (negative) horses; lameness evaluation, flexion test, $\mathrm{X}$-ray and arthroscopy. All of the examinations mentioned above were found to be negative, concluding that no evidence of articular pathology was found in the healthy controls. Ethical and legal approval was obtained from the Slovenian Veterinarian Administration to perform surgery on these animals for experimental purposes. 
Horses with osteochondral fragments of the extensor process were not included in the investigation, because they were considered as traumatically induced or as an unusual manifestation of osteochondrosis (Trotter 2003).

Synovial fluid samples

Synovial fluid was collected from the distal interphalangeal joints of 28 lame horses and 17 horses with no orthopaedic disease. The synovial fluid samples were stored at $+4{ }^{\circ} \mathrm{C}$ for no more than 24 hours before centrifugation at $10.000 \mathrm{~g}$ for $20 \mathrm{~min}$. Supernatants were aliquoted and stored at $-20^{\circ} \mathrm{C}$ until assayed.

Gelatin zymography

Gelatinase activity of the synovial fluid was assayed using gelatin zymography. A modified method of Laemmli (1970) was used for polyacrylamide gel electrophoresis (PAGE) using a $7.5 \%$ separating polyacrylamide gel $(0.75 \mathrm{~mm}$ thickness) containing $0.12 \%$ pig skin type I gelatin (Sigma). The $4 \%$ stacking gel contained no gelatin. The samples of synovial fluid, diluted 1: 1 in PBS, were denatured with SDS but not reduced. The mixture of molecular weight markers was diluted $1: 4$ with SDS reducing buffer and heated in a boiling waterbath for 5 min prior to loading on the gel. MMP-2 from human fibroblasts (Sigma) and MMP-9 from human fibroblasts (Sigma) were used as controls. Each dilution of $10 \mu \mathrm{ml}$ was loaded into a well and samples were electrophoresed at a constant $200 \mathrm{~V}$ for $45 \mathrm{~min}$. After electrophoresis, the proteins were allowed to renature by removing SDS by soaking the gel in $2.5 \%$ Triton $\mathrm{X}-100$ with gentle shaking for $30 \mathrm{~min}$ at room temperature. Gels were incubated overnight at $37^{\circ} \mathrm{C}$ in a reactivation buffer containing $50 \mathrm{mM}$ Tris/ $\mathrm{HCl}, 50 \mathrm{mM} \mathrm{CaCl}, 10 \mathrm{mM} \mathrm{NaCl}$ and $0.05 \%$ Brij 35 . Following incubation, the gels were stained for $20 \mathrm{~min}$ with $0.1 \%$ Coomassie brilliant blue R250 (Bio-Rad) in a solvent mixture containing $40 \%$ methanol and $10 \%$ acetic acid. After staining, the gels were destained in a solution of $40 \%$ methanol and $10 \%$ acetic acid until gelatinolytic bands could be seen. Stained gels were scanned using a Model GS-700 Imaging Densitometer (Bio-Rad).

Statistical analysis

The relationship between the results of complete clinical examination and arthroscopic, radiological examination and analysis involving various forms of MMP-2 and MMP-9, was displayed by contingency tables. Fisher exact test was performed to determine if there was any association between categorical data in the contingency table. Logistic regression was used to predict any association between the results of different diagnostic methods.

Diagnostic evaluation

Diagnostic evaluation was performed for both radiological examination and determination of MMP forms. Association between them was examined in $2 \times 2$ tables, using Fisher exact test.

Samples of synovial fluid were divided into positive (D+) and negative (D-) groups according to the results of clinical diagnosis. Results of substrate gel analysis for each MMP form were divided into positive $(\mathrm{T}+)$ and negative (T-) groups on the basis of their presence or absence on the gels. Results of radiological examination were also divided into positive $(\mathrm{T}+)$ and negative (T-) groups. Combining the results of the classifications $\mathrm{D}+/ \mathrm{D}-$ and $\mathrm{T}+/ \mathrm{T}-$, the results from each diagnostic tool (MMP forms and radiological examination) were divided into four categories: TP: true positive (D+, T+); TN: true negative (D-, T-); FN: false negative (D+, T-); FP: false positive (D-, T+).

Sensitivity, specificity, overall accuracy, positive predictive value and negative predictive value were calculated using the $2 \times 2$ table.

Sensitivity for each diagnostic tool was calculated as the proportion of true positives that were identified as positive by the diagnostic tool (TP/TP+FN) and specificity as the proportion of true negatives similarly identified as negative (TN/TN+FP). The predictive value of a positive result was calculated as the proportion of animals assessed as positive by a diagnostic tool that were, in fact, positive (TP/TP+FP) and the predictive value of a negative result as the proportion of animals assessed as negative that were, in fact, negative (TN/TN+FN).

Decision tree method

We illustrate the procedure when a test for MMP is performed in the case of a negative X-ray result. The problem is presented as a decision tree. Revision of diagnostic probabilities after performing the test is represented by the branch probabilities. The probability of a positive test result in case of negative radiological examination is written above the $\mathrm{T}+$ branch and a negative above the $\mathrm{T}$ - line. Results of arthroscopic examination are denoted by $\mathrm{D}+$ and $\mathrm{D}$ - and are illustrated in the decision tree by the two branches connected to both T+ and T- branches (Daw sonSaunders and Trapp 1994).

\section{Results}

\section{Presence of MMP-2 and MMP-9 in synovial fluid}

Gelatin zymograms of synovial fluid from normal and osteoarthritic joints show proteins of 64,000 and 94,000 mass, corresponding to monomeric proenzymes MMP-2 and MMP-9. In positive samples, bands at $59 \mathrm{kDa}$ (active form of MMP-2), $84 \mathrm{kDa}$ (active form of MMP-9) and $225 \mathrm{kDa}$ (dimer of MMP-9) were also observed (Plate IV, Fig. 1). Active forms of MMP2 and MMP-9 were observed in synovial fluid from osteoarthritic joints in $60.71 \%$ and $64.29 \%$ of cases, respectively (Table 1). In control samples they were observed less 
Table 1. Frequency of observation of MMP-2 and MMP-9 forms on gelatin zymograms

\begin{tabular}{|c|c|c|}
\hline \multirow[t]{2}{*}{$\begin{array}{l}\text { Apparent molecular } \\
\text { weight of MMP }(\mathrm{kDa})\end{array}$} & \multicolumn{2}{|c|}{$\begin{array}{c}\text { Frequency of observation of MMP forms } \\
\text { on gelatin zymograms }(\%)\end{array}$} \\
\hline & positive group & negative group \\
\hline \multicolumn{3}{|l|}{ MMP-2 } \\
\hline monomer, $64 \mathrm{kDa}$ & 100 & 100 \\
\hline active form, $59 \mathrm{kDa}$ & 60.71 & 11.76 \\
\hline \multicolumn{3}{|l|}{ MMP-9 } \\
\hline dimer, $225 \mathrm{kDa}$ & 50.00 & 21.43 \\
\hline monomer, $94 \mathrm{kDa}$ & 100 & 100 \\
\hline active form, $84 \mathrm{kDa}$ & 64.29 & 17.65 \\
\hline
\end{tabular}

frequently, MMP-2 in $11.76 \%$ and MMP-9 in 17.65\% (Table 1). These results are in accordance with previous studies, where the activation of MMP, which requires loss of an 8 to $10 \mathrm{kDa}$-terminal propeptide, was proposed as a fundamental step in articular cartilage degradation (Birkedal-Hansen et al. 1993). MMPs are secreted as inactive zymogens. Clegg and Carter (1999) predicted that activation of MMP-2 and MMP-9 may be important in causing matrix degradation in horse joints. The dimer of MMP-9 is observed more frequently in positive samples, but not significantly so $(P>0.05)$. The presence of active forms of MMP-2 and MMP-9 was associated with osteoarthritis $(P<0.05)$, whereas the other forms were not $(P>0.05)$. The band at $125 \mathrm{kDa}$ may correspond to an SDS-stable complex of MMP-2 and $\alpha-2$ macroglobulin related protein, which has a molecular weight of about $125 \mathrm{kDa}$ (Dean et al. 1989) (Fig.1). All enzymes with gelatinolytic activity were totally inhibited by $100 \mathrm{mM}$ EDTA in reactivation buffer.

Diagnostic parameters for radiological examination and detection of active forms of MMP-2 and MMP-9

Diagnostic parameters for the three methods (detection of active forms of MMP-2 and MMP-9 and radiological examination) are presented in Table 2. Positive arthroscopic examination was found in all cases of positive radiological examination. In all cases with confirmed osteoarthritis, cartilage damages were observed with arthroscopic examination.

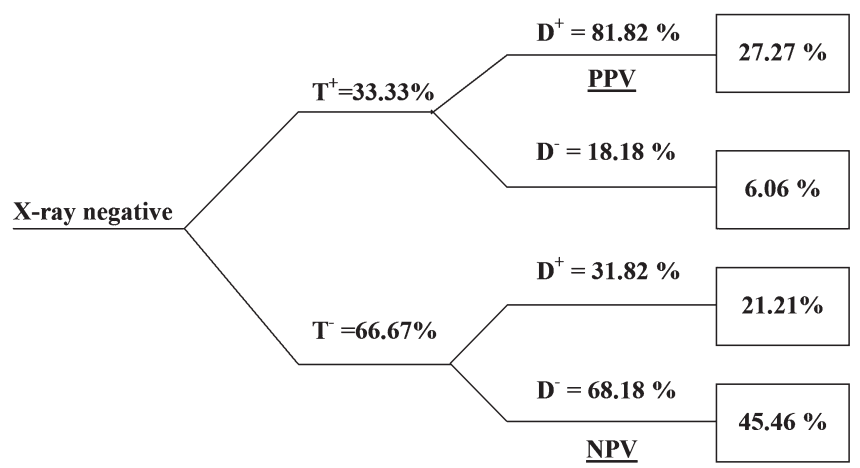

Fig. 2. Reversed decision tree for active form of MMP-2. The reversed decision tree for the active form of MMP2 represents the predictive value of observing the active form MMP- 2 in the case of a negative result in radiological examination.

$\mathrm{T}+$ and $\mathrm{T}-$ : probability of a positive and a negative test result in case of negative radiological examination

$\mathrm{D}+$ and D-: results of positive and negative arthroscopic examination

PPV and NPV: positive and negative predictive value 
The detection of active forms of MMP-2 (60.71\%) and MMP-9 (64.29\%) was found to provide a higher sensitivity diagnostic test than radiological examination $(42.86 \%)$. Radiological examination yielded high level of false negative results, which has been known for decades. Thus, detection of active forms of MMPs is more effective in identifying horses with osteoarthritis than radiological examination. The test for detecting active forms of MMPs also proved to be effective in correctly identifying animals without osteoarthritis. Specificity for the detection of active forms of MMP-2 and MMP-9 was high $(88.24 \%$ and $82.35 \%$, respectively). Negative predictive values were low for all three methods, varying from $51 \%$ to $58 \%$ (Table 2), indicating that none of the three methods gives a correct diagnosis when the animal has no osteoarthritis. On the other hand, a high proportion of animals with osteoarthritis tested positive for the disease, as shown by the high positive predictive values for the detection of active forms of MMP-2 and MMP-9 (89.47\% and $85.71 \%$, respectively) (Table 2 ).

Table 2. Diagnostic parameters for radiological examination and detection of active forms of MMP-2 and MMP-9

\begin{tabular}{|l|c|c|c|}
\hline \multirow{2}{*}{ Diagnostic parameters (\%) } & \multicolumn{3}{|c|}{ Method } \\
\cline { 2 - 4 } & X - ray & $\begin{array}{c}\text { MMP-2 } \\
\text { active form }\end{array}$ & $\begin{array}{c}\text { MMP-9 } \\
\text { active form }\end{array}$ \\
\hline sensitivity & 42.86 & 60.71 & 64.29 \\
\hline specificity & 100.00 & 88.24 & 82.35 \\
\hline accuracy & 71.43 & 74.47 & 73.32 \\
\hline positive predictive value & 100.00 & 89.47 & 85.71 \\
\hline negative predictive value & 51.52 & 57.69 & 58.33 \\
\hline
\end{tabular}

Multiple logistic regression, used to predict an association between two diagnostic methods, shows associations between arthroscopic examination and detection of active forms of both MMP- $2(P=0.006)$ and MMP-9 $(P=0.007)$. On the basis of multiple logistic regression, however, no association between arthroscopic and radiological examination was found $(P=0.926)$.

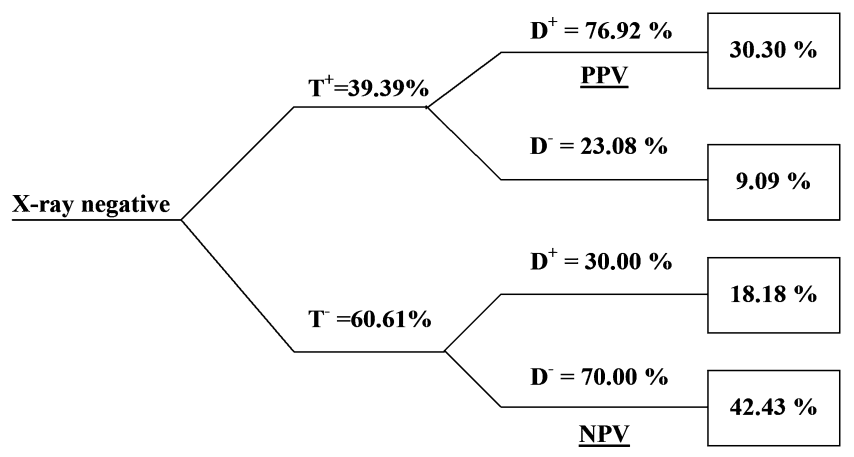

Fig. 3. Reversed decision tree for active form of MMP-9. Reversed decision tree for the active form of MMP-9 represents the predictive value of determining active form MMP-9 in the case of a negative result in radiological examination.

$\mathrm{T}+$ and $\mathrm{T}-$ : probability of a positive and a negative test result in case of negative radiological examination

$\mathrm{D}+$ and $\mathrm{D}-$-: results of positive and negative arthroscopic examination

PPV and NPV: positive and negative predictive value 
Contribution of MMP assays to clinical decision making

The contribution of the detection of active forms of MMP-2 and MMP- 9 in the case of a negative $\mathrm{X}$-ray result was analysed using a reversed decision tree.

The predictive values of a positive result (PPV) were calculated to be $81.82 \%$ (active form of MMP-2) and 76.92\% (active form of MMP-9), indicating a high percentage of animals that actually have osteoarthritis, giving a positive test result. On the other hand, lower negative predictive values (NPV), $68.18 \%$ and $70.00 \%$, were observed for active forms of MMP-2 and MMP-9, respectively (Fig. 2 and Fig. 3).

\section{Discussion}

This study shows that active forms of MMP-2 and MMP-9 are commonly found in the osteoarthritic distal interphalangeal joint in horses and can contribute to the diagnosis of osteoarthritis.

Only adult horses were included in our study. In the metacarpophalangeal joints of juvenile horses it has been shown that the high MMP activity is involved in physiological tissue remodelling during growth. In adult horses with no signs of osteoarthritis, MMP activity was low, and thus increased MMP activity in synovial fluid of mature horses was likely to indicate matrix destruction (Brama et al. 1998). For these reasons, MMP assay should prove a useful tool in diagnostic, therapeutic or prognostic studies on horses suspected of osteoarthritis, provided that age is taken into account ( $\mathrm{Brama}$ et al. 1998).

MMP-2 and MMP-9 were detected in synovial fluid using gelatin zymography, which allows measurement of total MMP activity. Furthermore, gelatin zymography allows identification of the individual enzymes and comparison of their enzyme activity between samples (Clegg et al. 1997), which was confirmed with the standards of MMP-2 and MMP-9 from human fibroblasts. No bands were seen on our gelatin zymograms after reactivation in a buffer containing $100 \mathrm{mM}$ EDTA, confirming that the lysis of the gelatin was due to matrix metalloproteases (Koolwijk et al. 1995; Clegg et al. 1997).

Monomers of MMP-2 and MMP-9 were not specific for osteoarthritis, since they also occurred in control samples. Gelatin zymography indicated that active forms of both gelatinases are present in the majority of synovial fluid samples from OA patients, whereas hardly any active forms of MMP were detectable in healthy controls. Clegg and Carter (1999) predicted that activation of MMP- 2 and MMP-9 may be important in causing matrix degradation in horse joints. Elevated MMP-2 and MMP-9 levels have also been observed in canine osteoarthritic and rheumatoid synovial fluid samples (Coughlan et al. 1995). Higher MMP-2 activity and dramatic increase in MMP-9 activity were associated with osteoarthiritic state, even though MMP-2 activity was detected in healthy joints of dogs (Volk et al. 2003). Levels of MMP-9 and MMP-2 activity were found to be higher in the synovial fluid of cows with septic and aseptic arthritis, respectively, than in fluids from normal joints (Arican et al. 2000).

The dimer of MMP-9 was observed more frequently in positive samples, as reported elsewhere (Trumble et al. 2001), although in our study the difference was not significant $(P>0.05)$. The dimerization is thought to occur only when MMP-9 is present in excess of its tissue inhibitor, and to be a critical step in the activation of MMP-9 (Clegg et al. 1997). Visible cartilage damage was fond with arthroscopic examination of all horses with osteoarthritis, therefore arthroscopy was proposed as the golden standard for diagnosis of osteoarthritis. All additional comparisons were performed between arhroscopy and other diagnostic methods.

Active forms of MMP-2 and MMP-9 are observed with $88.24 \%$ and $82.35 \%$ specificity, respectively, indicating the value of the test for excluding osteoarthritis. The low sensitivity of radiological examination $(42.86 \%)$ is due to many false negative results, whereas 
detection of active forms of MMP-2 (60.71\%) and MMP-9 (64.29\%) was found to be more sensitive. Therefore detection of active forms of MMP is more effective in diagnosing osteoarthritis than radiological examination. A correlation was observed between arthroscopy and the determination of the active forms of MMP-2 $(P=0.006)$ and MMP-9 $(P=0.007)$. On the other hand, no correlation was found between arthroscopy and X-ray examinations $(P=0.926)$.

The detection of active forms of MMP-2 and MMP-9 was evaluated as an additional diagnostic tool in the diagnosis of osteoarthritis. We analysed its contribution in the case of a negative X-ray result, because it has been shown that radiological examination often mistakenly identifies some horses with cartilage damage as non-osteoarthritic. The problem was structured as decision trees (Fig. 2 and 3), which could constitute a tool for the practitioner, who could find the information needed to take the results of detecting active forms of MMP into consideration. A reverse decision tree is presented to describe more accurately the situation confronting the physician; by putting the "test" first and then drawing a conclusion from the test results as to whether the disease is likely to be present. Our results indicate that the detection of MMP active forms, in addition to clinical examination, could improve the early diagnosis of osteoarthritis. The proportions of animals with confirmed osteoarthritis, showing a positive test result, were found to be $81.82 \%$ and $76.92 \%$, respectively, using the detection of active forms of MMP-2 and MMP-9. Thus, in the case of a negative X-ray result, a detectable active form of MMP-2 means that there is an $81.82 \%$ probability that cartilage damage is present. The corresponding negative predictive values were $68.18 \%$ and $70.0 \%$, respectively, indicating a lower accuracy, when animals have no osteoarthritis.

The results of this study confirm that active forms of MMP occur in synovial fluid of osteoarthritic joints more frequently than in synovial fluid of healthy joints of the horse. $\mathrm{V}$ an den Bloon et al. (2005) also found that general MMP activity in joint with moderate to severe cartilage damage is related to the severity of that cartilage damage. Detection of active forms of MMP-2 and MMP- 9 is shown to have an important diagnostic potential. Further, given the possibility of modulating MMP activity by MMP inhibitors, these enzymes may also be proving to be therapeutic targets (Arican et al. 2000). It has been shown that the increased TIMP levels in arthritic cartilage may not provide a sufficiently effective defence against cartilage destruction by MMPs (Huang et al. 2002). Therefore synthetic inhibitors could be of great value, for example $\mathrm{FR}_{255031}$, which significantly inhibited cartilage degradation in the rat collagen-induced arthritis model. These results suggest that inhibition of collagenases, gelatinases and MT-MMP is recommended in the treatment of arthritic joints (Ishikawa et al. 2005).

\section{Diagnostický význam metaloproteinázy matrix MMP-2 a MMP-9 v synovii pro diagnostiku osteoartritidy v kopytním kloubu u koní}

Naším cílem bylo zjistit diagnostický potenciál metaloproteinázy matrix MMP-2 a MMP-9 v diagnostice osteoartritidy u koní.

Koně byli rozděleni do dvou skupin. Pozitivní skupina sestávala z 28 koní s poškozením chrupavky kopytního kloubu a negativní skupina ze17 kontrolních koní. Klinické vyšetření koní zahrnovalo diagnostiku kulhání, flexní zkoušku, svodné znecitlivění, RTG a artroskopii. MMP-2 a MMP-9 byly detekovány v synoviální tekutině pomocí želatinové zymografie.

Ukázalo se, že monomery MMP-2 a MMP-9 nejsou specifické pro osteoartritis, protože byly detekovány i u kontrolních vzorkủ. Naproti tomu bylo zjištěno, že detekce aktivních forem obou enzymů byla v identifikaci koní s osteoartritidou úspěšnější než RTG vyšetření na základě vyšší sensitivity. Aktivní formy MMP-2 a MMP-9 byly zjištovány se specifitou 
$88,24 \%$ a 82,35 \%, což ukazuje vysokou přesnost ve správném určení koní bez osteoartritidy. Detekce MMP by mohla zlepšit diagnostiku osteoartritidy jako doplnění klinického vyšetření. Detekce aktivních forem MMP-2 a MMP-9 byla vyhodnocena jako doplňková forma diagnostiky osteoartritidy, obzvláště v případech negativního nálezu na RTG. Počty zvířat s potvrzenou osteoartritidou, která byla testována s pozitivním výsledkem, činily $81,82 \%$ a $76.92 \%$.

\section{Acknowledgements}

This work was supported by the Slovenian Research Agency, programe group "Endocrine, immune, nervous and enzyme responses in healty and sick animals" (P4-0053). Special thanks go to Prof. Janko Kos for valuable suggestions in diagnostic evaluation of the results. Many thanks to Dr. Brems, for suggestions on clinical examination and arthroscopy. Authors also thank Prof. Roger Pain for critical reading of the manuscript.

\section{References}

ALLAN JA, DOCHERTY AJ, BARKER PJ HUSKISSON NS, REYNOLDS JJ, MURPHY G 1995: Binding of gelatinases A and B to type-I collagen and other matrix components. Biochem J 309: 229-306

ARICAN M, COUGHLAN AR, CLEGG PD, CARTER SD 2000: Matrix metalloproteinases 2 and 9 activity in bovine synovial fluids. J Vet Med A-Physiol Pathol Clin 47: 449-456

BIRKEDAL-HANSEN H, MOORE WG, BODDEN MK WINDSOR LJ, BIRKEDAL-HANSEN B, DECARLO A, ENGLER JA 1993: Matrix metalloproteinases: a review. Crit Rev Oral Biol Med 4: 197-250

BRAMA PA, TEKOPPELE JM, BEEKMAN B, VAN WEEREN PR, BARNEVELD A 1998: Matrix metalloproteinase activity in equine synovial fluid: influence of age, osteoarthritis, and osteochondrosis. Ann Rheum Dis 57: 697-699

CLEGG PD, COUGHLAN AR, RIGGS CM, CARTER SD 1997: Matrix metalloproteinases 2 and 9 in equine synovial fluids. Equine Vet J 29: 343-48

CLEGG PD, COUGHLAN AR, CARTER SD 1998: Equine TIMP-1 and 2: Identification, characterisation and cellular sources in joint disease. Equine Vet J 30: 416-423

CLEGG PD, CARTER SD 1999: Matrix metalloproteinase-2 and -9 are activated in joint diseases. Equine Vet J 31: 324-330

COUGHLAN AR, CARTER SD, ROBERTON DHL 1995: Zymography analysis of synovial fluid metalloproteinases in canine osteoarthritis. Vet Comp Orth Traum 8: 62

CRUWYS SC, DAVIES DE, PETTIPHER ER 1990: Co-operation between interleukin-1 and the fibrinolytic system in the degradation of collagen by articular chondrocytes. Brit J Pharmacol 100: 631-635

DAWSON-SAUNDERS B, TRAPP RG 1994: Evaluating diagnostic procedures. In: Basic and clinical biostatistics. London: Prentice- Hall International, UK, pp. 232-49.

DEAN DD, MARTEL-PELLETIER J, PELLETIER JP, HOWELL DS, WOESSNER JF JR1989: Evidence of metalloproteinase and metalloproteinase inhibitor imbalance in human osteoarthritic cartilage. J Clin Invest 84 : 678-685

GIBSON KT, HODGE H, WHITTEM T 1996: Inflammatory mediators in equine synovial fluid. Aust Vet J 73: 148-151

HUANG W, LI WO, DEHNADE F, ZAFARULLAH M 2002: Tissue inhibitor of metalloproteinase-4 (TIMP-4) gene expression is increased in human osteoarthritic femoral head cartilage. J Cell Biochem 85: 295-303

ISHIKAWA T, NISHIGAKI F, MIYATA S, HIRAYAMA Y, MINOURA K, IMANISHI J, NEYA M, MIZUTANI T, IMAMURA Y, NARITOMI Y, MURAI H, OHKUBO Y, KAGAYAMA A, MUTOH S 2005. Prevention of progressive joint destruction in collagen-induced arthirits in rats by novel matrix metalloproteinase inhibitor, FR 25031 . Brit J Pharmacol 144: 133- 143

KOOLWIJK P, MILTENBURG AM, VAN ERCK MG OUDSHOORN M, NIEDBALA MJ, BREEDVELD FC, VAN HINSBERG VW 1995: Activated gelatinase-B (MMP-9) and Urokinase-Type Plasminogen Activator in Synovial Fluids of Patients with Arthritis. Correlation with Clinical and Experimental Variables of Inflammation. J Rheumatol 22: 385-93

LAEMMLI UK 1970: Cleavage of structural proteins during assembly of the head of bacteriophage T4. Nature 227: $680-685$

LEBER TM, BALKWILL FR 1998. Regulation of monocyte MMP-9 production by TNF-a and a tumor-derived soluble factor (MMPSF). Brit J Cancer 78: 724-732

LEFEBVRE V, PEETERS-JORIS C, VAES G 1990: Modulation by interleukin 1 and tumor necrosis factor alpha of production of collagenase; tissue inhibitor of metalloproteinases and collagen types in differentiated and dedifferentiated articular chondrocytes. Biochim Biophys Acta 1052: 366-378

LOHMANDER LS, LARK MW, DAHLBERG L WALAKOVITS LA, ROOS H 1992: Cartilage Matrix Metabolism in Osteoarthritis: Markers in Synovial Fluid, Serum, and Urine. Clin Biochem 25: 167-174

MCILWRAITH CW, VACHON A 1988: Rewiev of pathogenesis and treatment degenerative joint disease. Equine Vet J Suppl. 6: 3-11 
MCILWRAITH CW 2005: Use of synovial fluid and serum biomarkers in equine bone and joint disease: a review. Equine Vet J: 37: 473- 82

PELLETIER AP, MINEAU F, FAURE MP, MARTEL-PELLETIER J 1990: Imbalance between the mechanism of activation and inhibition of metalloproteases in the early lesions of experimental osteoarthritis. Arth Rheum 33: $1466-1476$

PONTON A, COULOMBE B, SKUP D 1991: Decrease expression of tissue inhibitor of metalloproteinases in metastatic tumor cells leading to increased levels of collagenase activity. Cancer Res 51: 2138- 43

RØRVIK AM, GRØNDAHL AM 1995: Markers of Osteoartrhritis: A Review of the Literature. Vet Surg 24: $255-62$

SIER C, CASETTA G, VERHEIEN JH TIZZANI A, AGAPE V, KOS J, BLASI F, HANEMAAIJER R 2000: Enchanced urinary gelatinase activity (matrix metalloproteinases 2 and 9) are associated with early-stage bladder carcinoma: a comparison with clinically used tumor markers. Clin Cancer Res 6: 2333-2340

TROTTER G 2003: Fractures and fragmentation of the extensor process of the distal phalanx. In: Ross MW, Dyson SJ eds. Lameness in the horse. Philadelphia: WB Saunders Co, USA, pp. 316-317.

TRUMBLE TN, TROTTER GW, OXFORD J JR MCILWRAIGHT CW, CAMMARATA S, GOODNIGHT JL, BILLINGHURST RC, FRISBIE DD 2001: Synovial fluid gelatinase concentrations and matrix metalloproteinase and cytokine expression in naturally occurring joint disease in horses. Am J Vet Res 62): 14671477

VAN DEN BOOM R, VAN DER HARST MR, BROMMER H, BRAMA PA, BARNEVELD A, VAN WEEREN PR, DEGROOT J 2005: Relationship between synovial fluid levels of glycosaminoglycans, hydroxyproline and general MMP activity and the presence and severity of articular cartilage change on the proximal articular surface of P1. Equine Vet J 37: 19-25

VOLK SW, KAPATKIN AS, HASKINS ME, WALTON RM, D'ANGELO M 2003: Gelatinase activity in synovial fluid and synovium obtained from healthy and osteoarthritic joints of dogs. Am J Vet Res 64: 1225-33

WOESSNER JF 1991: Matrix metalloproteinases and their inhibitors in connective tissue remodelling. FASEB J 5: $2145-54$ 


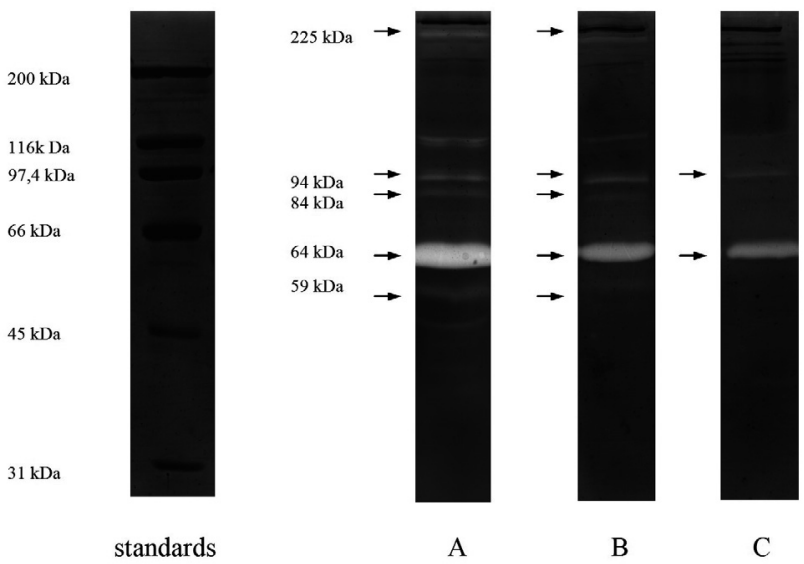

Fig. 1. Gelatin zymograms of synovial fluids. The molecular masses of different forms of MMP-2 and MMP-9 with gelatinolytic activity are shown (arrows). Molecular weight markers are shown at the left. Lanes $\mathrm{A}$ and $\mathrm{B}$ correspond to 2 synovial fluids from osteoarthritic patient and lane $\mathrm{C}$ to a control synovial sample. 